University of Nebraska - Lincoln

DigitalCommons@University of Nebraska - Lincoln

Publications from USDA-ARS / UNL Faculty

U.S. Department of Agriculture: Agricultural

Research Service, Lincoln, Nebraska

2007

\title{
Effect of Drying on Phosphorus Distribution in Poultry Manure
}

Heidi W. Dail

United States Department of Agriculture-Agricultural Research Service

Zhongqi He

United States Department of Agriculture-Agricultural Research Service, Zhongqi.He@ars.usda.gov

M. Susan Erich

University of Maine

C. Wayne Honeycutt

United States Department of Agriculture-Agricultural Research Service

Follow this and additional works at: https://digitalcommons.unl.edu/usdaarsfacpub

Part of the Agricultural Science Commons

Dail, Heidi W.; He, Zhongqi; Erich, M. Susan; and Honeycutt, C. Wayne, "Effect of Drying on Phosphorus Distribution in Poultry Manure" (2007). Publications from USDA-ARS / UNL Faculty. 527.

https://digitalcommons.unl.edu/usdaarsfacpub/527

This Article is brought to you for free and open access by the U.S. Department of Agriculture: Agricultural Research Service, Lincoln, Nebraska at DigitalCommons@University of Nebraska - Lincoln. It has been accepted for inclusion in Publications from USDA-ARS / UNL Faculty by an authorized administrator of DigitalCommons@University of Nebraska - Lincoln. 


\title{
Effect of Drying on Phosphorus Distribution in Poultry Manure
}

\author{
Heidi W. Dail \\ United States Department of Agriculture-Agricultural Research \\ Service, New England Plant, Soil, and Water Laboratory, Orono, \\ Maine, USA and Department of Plant, Soil and Environmental \\ Sciences, University of Maine, Orono, Maine, USA

\section{Zhongqi He} \\ United States Department of Agriculture-Agricultural Research Service, \\ New England Plant, Soil, and Water Laboratory, Orono, Maine, USA

\section{Susan Erich} \\ Department of Plant, Soil and Environmental Sciences, University \\ of Maine, Orono, Maine, USA

\section{Wayne Honeycutt} \\ United States Department of Agriculture-Agricultural Research Service, \\ New England Plant, Soil, and Water Laboratory, Orono, Maine, USA
}

\begin{abstract}
Laboratory drying may alter manure phosphorus (P) distribution. The effects of freeze, air $\left(22^{\circ} \mathrm{C}\right)$, and oven $\left(65^{\circ} \mathrm{C}\right)$ drying on sequentially fractioned poultry manure $\mathrm{P}$ were examined. Higher drying temperatures resulted in lower percentage of dry matter. Increased $\mathrm{H}_{2} \mathrm{O}$ - and decreased sodium bicarbonate $\left(\mathrm{NaHCO}_{3}\right)$-extractable $\mathrm{P}$ with drying provided evidence that drying increases poultry manure $\mathrm{P}$ solubility. Labile fractions were predominantly inorganic $\mathrm{P}\left(\mathrm{P}_{\mathrm{i}}\right)$, whereas sodium hydroxide $(\mathrm{NaOH})$ and hydrochloric acid $(\mathrm{HCl})$ fractions had significant amounts of organic $\mathrm{P}$ $\left(\mathrm{P}_{\mathrm{o}}\right.$ ). Drying altered $\mathrm{H}_{2} \mathrm{O}$ - and $\mathrm{NaHCO}_{3}$-extractable $\mathrm{P}_{\mathrm{i}}$ but had no consistent effect on $\mathrm{P}_{\mathrm{o}}$ in these fractions. This work suggests that variations due to drying should be

Received 15 June 2006, Accepted 11 October 2006

Trade or manufacturers' names mentioned in the article are for information only and do not constitute endorsement, recommendation, or exclusion by the USDA-ARS.

Address correspondence to Zhongqi He, United States Department AgricultureAgricultural Research Service, New England Plant, Soil, and Water Laboratory, University of Maine, Orono, ME 04469, USA. E-mail: zhongqi.he@ars.usda.gov
\end{abstract}


taken into consideration when evaluating manures for $\mathrm{P}$ availability or when comparing data in which different drying methods have been utilized.

Keywords: Inorganic phosphorus, manure drying, organic phosphorus, phosphorus, poultry manure, sequential phosphorus fractionation, total phosphorus

\section{INTRODUCTION}

Animal manures are rich in plant nutrients and have traditionally served as a valuable fertilizer resource for cropland. However, modern intensive animal and crop production systems are becoming more spatially separate, leading to concentration of surplus nutrients in areas surrounding livestock operations. Effective management practices are needed to optimize manure recycling while limiting risk of adverse environmental impact from nutrient runoff. A more thorough understanding of phosphorus $(\mathrm{P})$ characteristics from manure fertilizers is essential to reach this goal.

The nonuniform composition and high moisture content of most manure samples necessitate sample pretreatments (i.e., homogenization, drying, and grinding) prior to laboratory analysis. Frequently used drying processes include air drying $\left(22^{\circ} \mathrm{C}\right)$ (Elias-Azar, Laag, and Pratt 1980; He et al. 2006a), oven drying $\left(65\right.$ or $105^{\circ}$ C) (Akinremi et al. 2003; Dou et al. 2000; Sharpley and Moyer 2000), and freeze drying (He et al. 2004b; Leinweber, Haumaier, and Zech 1997). Comparative investigations have shown that manure $\mathrm{P}$ is affected by drying process (Ajiboye, Akinremi, and Racz 2004; Akinremi et al. 2003; Gerritse and Eksteen 1978; Sistani et al. 2001). Sistani et al. (2001), in a study on the effects of drying method on nutrient composition of manure from broiler chickens, noted that freeze or oven drying $\left(105^{\circ} \mathrm{C}\right)$ resulted in lower inorganic $\mathrm{P}\left(\mathrm{P}_{\mathrm{i}}\right)$ and total $\mathrm{P}\left(\mathrm{P}_{\text {tot }}\right)$ concentrations than air drying. Akinremi et al. (2003) examined $\mathrm{P}_{\text {tot }}$ concentrations of freeze-dried, air-dried $\left(30^{\circ} \mathrm{C}\right)$, and $105^{\circ} \mathrm{C}$-dried organic amendments (poultry, cattle, and pig manure) and found that $105^{\circ} \mathrm{C}$-dried samples had lower $\mathrm{P}_{\text {tot }}$ concentrations than manures dried under other conditions. In addition, Chapuis-Lardy et al. (2004) reported lower water-soluble $\mathrm{P}_{\mathrm{i}}$ concentrations in dried dairy manure than in fresh wet feces from a diverse group of commercial dairy farms in the northeastern United States.

Phosphorus $\left(\mathrm{P}_{\mathrm{i}}\right)$ solubility is primarily related to the solubility constants of mineral phosphates, and temperature may influence particular products formed (Gerritse and Eksteen 1978). Effects of drying on organic phosphorus $\left(\mathrm{P}_{\mathrm{o}}\right)$ are not as clear. Solubility of $\mathrm{P}_{\mathrm{o}}$ in pig slurry was not affected by drying $\left(0-100^{\circ} \mathrm{C}\right)$ and redispersion in water (Gerritse and Eksteen 1978). Furthermore, freeze- and $65^{\circ} \mathrm{C}$-dried samples of broiler manure had only a slight decrease in $\mathrm{P}_{\mathrm{o}}$, whereas $\mathrm{P}_{\mathrm{i}}$ content decreased up to $37 \%$ with drying (Sistani et al. 2001).

Sequential fractionation has been used to investigate $\mathrm{P}$ forms in soils and manures, as well as their transformation under various environmental 
conditions (Ajiboye, Akinremi, and Racz 2004; Akinremi et al. 2003; He, Griffin, and Honeycutt 2004a, 2004b; He et al. 2006a; Hedley, Stewart, and Chauhan 1982; Leinweber, Haumaier, and Zech 1997; Schlicting and Leinweber 2002). This method applies a series of extractants, such as water $\left(\mathrm{H}_{2} \mathrm{O}\right)$, sodium bicarbonate $\left(\mathrm{NaHCO}_{3}\right)$, sodium hydroxide $(\mathrm{NaOH})$, and hydrochloric acid $(\mathrm{HCl})$, to functionally separate $\mathrm{P}$ into fractions according to lability. Thus, sequential fractionation enables characterization of multiple $\mathrm{P}$ forms, providing greater insight into how drying processes affect $\mathrm{P}$ distribution than would $\mathrm{P}$ determination with a single extraction or digestion. Using this procedure, Ajiboye, Akinremi, and Racz (2004) characterized the influence of $105^{\circ} \mathrm{C}$ drying on $\mathrm{P}$ forms in different animal manures. Drying at $105^{\circ} \mathrm{C}$ increased $\mathrm{H}_{2} \mathrm{O}$-extractable $\mathrm{P}_{\mathrm{i}}$ in both swine and dairy manures. In swine manure, the major contributor to the increase was hydrolysis of $\mathrm{H}_{2} \mathrm{O}$-extractable $\mathrm{P}_{\mathrm{o}}$ to $\mathrm{H}_{2} \mathrm{O}$-extractable $\mathrm{P}_{\mathrm{i}}$; however, in dairy manure, the transformation occurred between fractions, with both $\mathrm{NaHCO}_{3}$-extractable $\mathrm{P}_{\mathrm{i}}$ and $\mathrm{NaHCO}_{3}$-extractable $\mathrm{P}_{\mathrm{o}}$ converted to $\mathrm{H}_{2} \mathrm{O}$ soluble forms. In addition, changes have been found in the more stable $\mathrm{P}$ forms of manure with drying. Schlichting and Leinweber (2002) investigated the effects of drying on sequentially extracted $\mathrm{P}$ fractions from organic peat soils. Drying led to substantial increases in residual $\mathrm{P}$ concurrent with decreases in $\mathrm{NaHCO}_{3}-$ and $\mathrm{NaOH}$-extractable $\mathrm{P}_{\mathrm{o}}$ fractions.

Poultry manure is an excellent source of plant nutrients, including P. Evaluation of the effect of drying on poultry manure $\mathrm{P}$ distribution will improve accuracy in characterization of this type of manure, a critical step in developing sound P-management practices. This study was conducted to compare $\mathrm{P}$ characteristics of poultry manures after freeze drying, air drying $\left(22^{\circ} \mathrm{C}\right)$, and oven drying $\left(65^{\circ} \mathrm{C}\right)$. In addition, to find an efficient method for evaluating plant-available $\mathrm{P}$ in poultry manure, the relationship of $\mathrm{P}$ extracted by a single sodium acetate buffer $(100 \mathrm{mM}, \mathrm{pH} 5.0)$ with $\mathrm{P}$ in sequentially extracted fractions was evaluated.

\section{MATERIALS AND METHODS}

\section{Manures}

Fresh poultry manure samples were collected from caged layer hens at two commercial egg farms in central Maine. A total of three manure samples were collected; PM-1, from layer house with daily waste removal; PM-2, layer house with a single annual cleaning; and PM-3, house with 13-weekold growing birds that received cleaning weekly. In addition to fecal material, the manure waste contained some feathers and dropped feed. For each of the three manures, five grab samples of manure were removed from inside of the poultry house, pooled, and stored in an airtight container at $4^{\circ} \mathrm{C}$. Manures were then homogenized using a food processor. Undried 
Table 1. Characteristics of poultry manures used in this study

\begin{tabular}{|c|c|c|c|c|c|c|c|c|c|c|}
\hline Manure & P & $\mathrm{Fe}$ & $\mathrm{Al}$ & Mn & $\mathrm{Ca}$ & $\mathrm{Mg}$ & $\mathrm{C}$ & K & $\begin{array}{c}\mathrm{EC} \\
\left(\mathrm{ds}^{-1}\right)\end{array}$ & $\mathrm{pH}$ \\
\hline \multicolumn{11}{|c|}{$\mathrm{g} \mathrm{kg}^{-1}$ dry matter $^{a}$} \\
\hline PM-2 & $19.0 \pm 2.1$ & $2.54 \pm 0.36$ & $1.04 \pm 0.17$ & $0.36 \pm 0.04$ & $152 \pm 11$ & $11.0 \pm 0.4$ & $278 \pm 14$ & $34.6 \pm 3.7$ & 12.5 & 7.96 \\
\hline PM-3 & $27.8 \pm 3.5$ & $1.65 \pm 0.12$ & $0.78 \pm 0.08$ & $0.54 \pm 0.07$ & $70.5 \pm 1.4$ & $11.3 \pm 1.5$ & $379 \pm 2$ & $44.4 \pm 0.4$ & 20.2 & 7.00 \\
\hline
\end{tabular}

${ }^{a}$ Dry matter based $105^{\circ} \mathrm{C}$-dried sample data from the maine agricultural and forestry experiment station analytical laboratory.

${ }^{b}$ Average from three replicate samples \pm standard deviation. 
manures were maintained at $-20^{\circ} \mathrm{C}$. Selected manure properties (Table 1) were determined by the Maine Agricultural and Forestry Experiment Station (MAFES) Analytical Laboratory. Manure was dry ashed at $550^{\circ} \mathrm{C}$ for $6 \mathrm{~h}$, and the ash was dissolved in $50 \% \mathrm{HCl}$. The resulting solution was analyzed by inductively coupled plasma to atomic emission spectroscopy (ICP-AES) for P, potassium (K), calcium (Ca), magnesium $(\mathrm{Mg})$, iron $(\mathrm{Fe})$, aluminum (Al), and manganese (Mn) using a ThermoJarrell Ash IRIS 1000. Carbon content of the manure samples was determined by combustion using a Leco CN2000 analyzer. Electrical conductivity (EC) and pH were determined using a 6:1 water $(\mathrm{mL})$ to freeze-dry manure $(\mathrm{g})$ ratio. A portion of each manure was desiccated via 1) oven drying at $65^{\circ} \mathrm{C}, 2$ ) air drying at $22^{\circ} \mathrm{C}$, or 3 ) freeze drying, until no further decrease in weight was observed. After drying, the manures were ground in a Wiley mill, sieved through a 2-mm screen, and stored at $-20^{\circ} \mathrm{C}$ until analysis.

\section{Sequential Fractionation}

A modified Hedley sequential fractionation procedure as described by $\mathrm{He}$, Griffin, and Honeycutt (2004a) was used in this study. Each sample (0.25 g, $65^{\circ} \mathrm{C}$ dry equivalent) was sequentially extracted in $25 \mathrm{~mL}$ of distilled water, $0.5 \mathrm{M} \mathrm{NaHCO}_{3}(\mathrm{pH} 8.5), 0.1 \mathrm{M} \mathrm{NaOH}$, and $1 \mathrm{M} \mathrm{HCl}$ for $2 \mathrm{~h}$ (water) or $16 \mathrm{~h}$ (all others) at $22^{\circ} \mathrm{C}$ on an orbital shaker at $250 \mathrm{rpm}$. After each extraction, the tubes were centrifuged at $23,700 \times \mathrm{g}$ for $30 \mathrm{~min}$ at $4{ }^{\circ} \mathrm{C}$. The supernatant was passed through a $0.45-\mu \mathrm{m}$ filter (Fisherbrand MCE membrane; Fisher Scientific, Pittsburgh, PA). The $\mathrm{NaHCO}_{3}, \mathrm{NaOH}$, and $\mathrm{HCl}$ fractions were diluted and adjusted to $\mathrm{pH}$ 5.0. Ethylenediamine tetraacetic acid (EDTA) (1 $\mathrm{mM}$ final concentration) was added to the $\mathrm{NaOH}$ fraction to prevent $\mathrm{P}$ compounds from precipitating during $\mathrm{pH}$ adjustment. Manure samples $\left(0.25 \mathrm{~g}, 65^{\circ} \mathrm{C}\right.$ dry equivalent) were also separately extracted with $25 \mathrm{~mL}$ of $100 \mathrm{mM} \mathrm{Na}$ acetate buffer ( $\mathrm{pH}$ 5.0) for $1 \mathrm{~h}$, followed by an additional extraction with $10 \mathrm{~mL}$ of buffer for $1 \mathrm{~h}$. Centrifugation and filtration were performed as previously described. Both acetate buffer extracts were combined. All extractions were performed with nine replications.

\section{Phosphorus Determination}

$\mathrm{P}_{\mathrm{i}}$ was determined using a modified molybdate blue method (He and Honeycutt 2005). $\mathrm{P}_{\text {tot }}$ concentrations of manures and extracts were determined by ICPAES after dry combustion at $550^{\circ} \mathrm{C}$ and digestion in $0.5 \mathrm{M}$ sulfuric acid $\left(\mathrm{H}_{2} \mathrm{SO}_{4}\right)$. Phosphorus $\left(\mathrm{P}_{\mathrm{o}}\right)$ was estimated as the difference between $\mathrm{P}_{\text {tot }}$ and $\mathrm{P}_{\mathrm{i}}$. Residual $\mathrm{P}$ was calculated as the difference between manure $\mathrm{P}_{\text {tot }}$ determined as described previously and the sum of $\mathrm{P}_{\text {tot }}$ extracted by all four extractants. 


\section{Statistical Analysis}

Statistical analyses were performed using SAS (1999). One-way analysis of variance (ANOVA) was computed to examine the effects of drying and extractant. Significance of differences among treatments was determined by mean separation using Fisher's least significant difference test.

\section{RESULTS AND DISCUSSION}

\section{Effect of Drying Processes on Dry-Matter Content}

The three poultry manures contained about $24-38 \%$ dry matter (DM) when dried at $105^{\circ} \mathrm{C}$ (Table 2). DM content was altered by the drying procedures. The general trend was that higher drying temperatures (from 22 to $105^{\circ} \mathrm{C}$ ) resulted in lower DM. This observation seems reasonable because temperature increases would cause interlayered water molecules to become more active and thus easier to drive off from the manure matrix. The near vacuum condition $(<500 \mathrm{mT})$ created by freeze drying was as effective as high temperatures in removing manure moisture from PM-2 and PM-3 but not from PM-1. Despite the trend toward increased moisture removal with higher temperatures, overall change in DM with drying method was not consistent across manures. Drying process had little effect on DM content of PM- 1 , but $105^{\circ} \mathrm{C}$-dried PM-2 had only $38 \%$ DM compared to $49 \%$ DM for $22^{\circ} \mathrm{C}$-dried PM-2. Manure properties, such as water-holding capacity and concentration of intracrystalline water, may have contributed to this variation. As an example, exceptionally low vapor pressure maintained over samples during extensive freeze drying has the capacity to evaporate intergranular pore water but cannot release that portion of moisture present as intracrystalline water. In contrast, high temperatures associated with oven drying could decompose crystalline water and other labile compounds, leading to additional moisture loss. Scholl et al. (1997) stated that drying at $105^{\circ} \mathrm{C}$ more aggressively (i.e., completely) evaporated interlayered water in sediment samples than other drying

Table 2. Effects of drying on dry matter content (\%)

\begin{tabular}{llll}
\hline Treatment & PM-1 & PM-2 & PM-3 \\
\hline Freeze dry & $33.2 \mathrm{a}$ & $40.3 \mathrm{c}$ & $26.9 \mathrm{~b}$ \\
Air $\left(22^{\circ} \mathrm{C}\right)$ & $33.0 \mathrm{a}$ & $48.8 \mathrm{a}$ & $30.5 \mathrm{a}$ \\
Oven $\left(65^{\circ} \mathrm{C}\right)$ & $30.0 \mathrm{~b}$ & $41.6 \mathrm{~b}$ & $24.7 \mathrm{~b}$ \\
Oven $\left(105^{\circ} \mathrm{C}\right)$ & $30.0 \mathrm{~b}$ & $38.3 \mathrm{~d}$ & $24.0 \mathrm{~b}$ \\
\hline
\end{tabular}

Note. Averages followed by the same letter for each manure are not significantly different ( $\alpha=0.05)$. 
methods. They also determined that oven-dried porosity values of sediment samples exceeded those of freeze-dried samples, whereas no difference was recorded between oven- and freeze-dried samples of artificial sediments (glass beads and seawater) that lack a clay component. Further validating our observation of drying effects, Akinremi et al. (2003) noted that $105^{\circ} \mathrm{C}$-dried samples contained less moisture than manures subjected to other drying methods, but no difference was distinguished between freeze- and air- $\left(30^{\circ} \mathrm{C}\right)$ dried poultry manure samples. The inconsistent impact of drying on different samples suggests caution be taken when comparing published $\mathrm{P}$ data in which DM is calculated based on different drying processes.

\section{Effect of Drying on P Distribution in Sequentially Extracted Fractions}

Of the $\mathrm{P}_{\text {tot }}$ in the undried manure samples, $11-20 \%$ was $\mathrm{H}_{2} \mathrm{O}$ extractable, 19$37 \%$ was $\mathrm{NaHCO}_{3}$ extractable, $3-8 \%$ was $\mathrm{NaOH}$ extractable, $31-45 \%$ was $\mathrm{HCl}$ extractable, and $0-25 \%$ was residual (Figure 1). Water-extractable $\mathrm{P}$ in manure is correlated with $\mathrm{P}$ in runoff from recently amended soils and is increasingly used as an indicator of environmental risk (Kleinman et al. 2002, 2005). All drying methods increased the quantity of $\mathrm{H}_{2} \mathrm{O}$-extractable $\mathrm{P}$ in PM-1 and PM-3 with the greatest change in $65^{\circ} \mathrm{C}$ drying, followed by $22^{\circ} \mathrm{C}$ drying, and then freeze drying. Drying at $65^{\circ} \mathrm{C}$ also increased $\mathrm{H}_{2} \mathrm{O}-$ extractable $\mathrm{P}$ in $\mathrm{PM}-2$. Increased drying temperature could cause sorbed $\mathrm{P}$ to become more $\mathrm{H}_{2} \mathrm{O}$ soluble. Previous studies have yielded conflicting results on the effects of drying on $\mathrm{H}_{2} \mathrm{O}$-extractable $\mathrm{P}$ in manures, and it appears that $\mathrm{P}$ solubility is related to specific manure chemicophysical characteristics (Ajiboye, Akinremi, and Racz 2004; Kleinman et al. 2002, 2005; Sistani et al. 2001). Ajiboye, Akinremi, and Racz (2004) reported $105^{\circ} \mathrm{C}$ dried dairy manure contains $25 \%$ more $\mathrm{H}_{2} \mathrm{O}$-extractable $\mathrm{P}$ than undried samples but did not see similar effects in swine or beef cattle manure. In contrast, poultry manure has been found to have decreased $\mathrm{H}_{2} \mathrm{O}$-extractable $\mathrm{P}$ with air, $65^{\circ} \mathrm{C}$, and freeze drying but little change with drying at $105^{\circ} \mathrm{C}$ (Sistani et al. 2001). Incorporation of $\mathrm{P}$ into aggregated particles during dehydration has been suggested as a possible cause for decreased bioavailable $\mathrm{P}$ in air-dried sediment samples (Twinch 1987). These differential effects of drying on $\mathrm{H}_{2} \mathrm{O}$-extractable $\mathrm{P}$ reflect the complex nature of animal manure and our associated lack of understanding this complexity.

Drying decreased $\mathrm{P}$ extracted by $\mathrm{NaHCO}_{3}$ (Figure 1). Manures dried at $65^{\circ} \mathrm{C}$ and freeze dried had $20-51 \%$ and $11-47 \%$ less $\mathrm{NaHCO}_{3}$-extractable $\mathrm{P}$ compared to undried manure, respectively. Air drying had a similar effect with $18-28 \%$ lower $\mathrm{NaHCO}_{3}$-extractable $\mathrm{P}$ than undried manure. The smallest extracted fraction was $\mathrm{NaOH}-\mathrm{P}$, comprising an average of $6 \%$ of total $\mathrm{P}$ for the manures. Small but significant decreases in $\mathrm{NaOH}$-extractable $\mathrm{P}$ occurred in PM-1 with all drying types. Differences in $65^{\circ} \mathrm{C}$ - and freeze- 
a) $\mathrm{PM}-1$

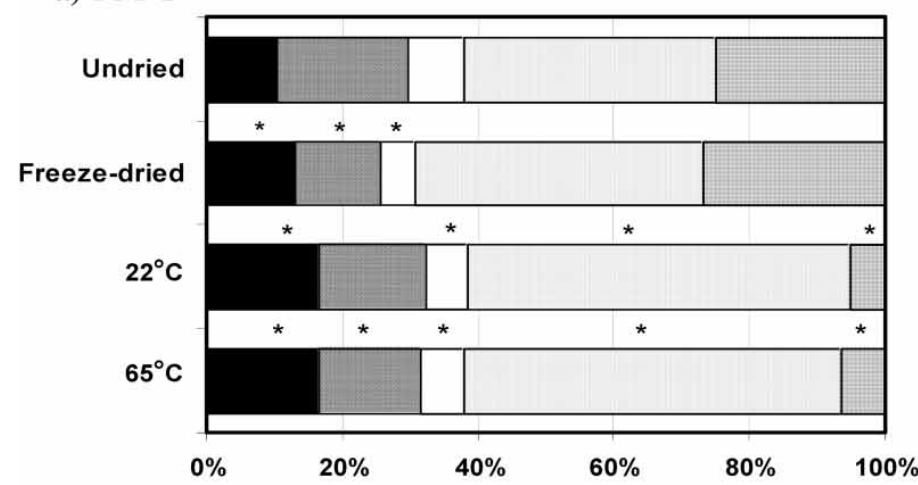

b) PM-2

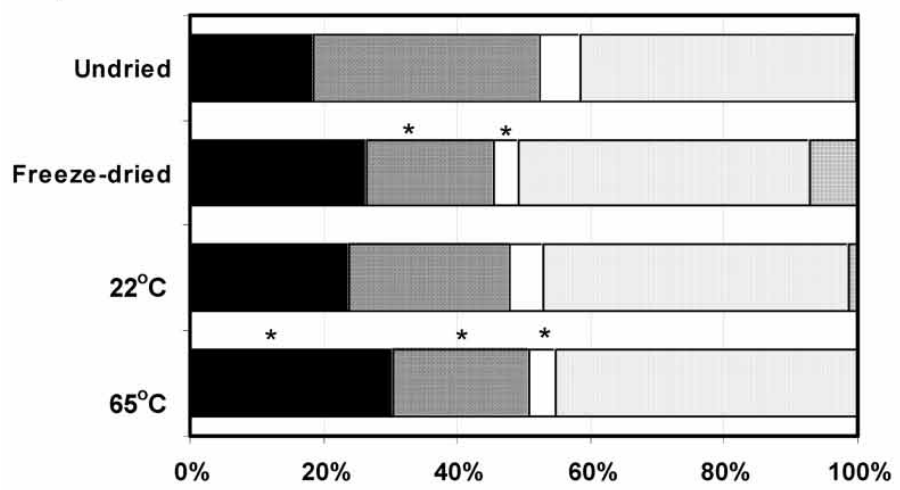

c) $\mathrm{PM}-3$

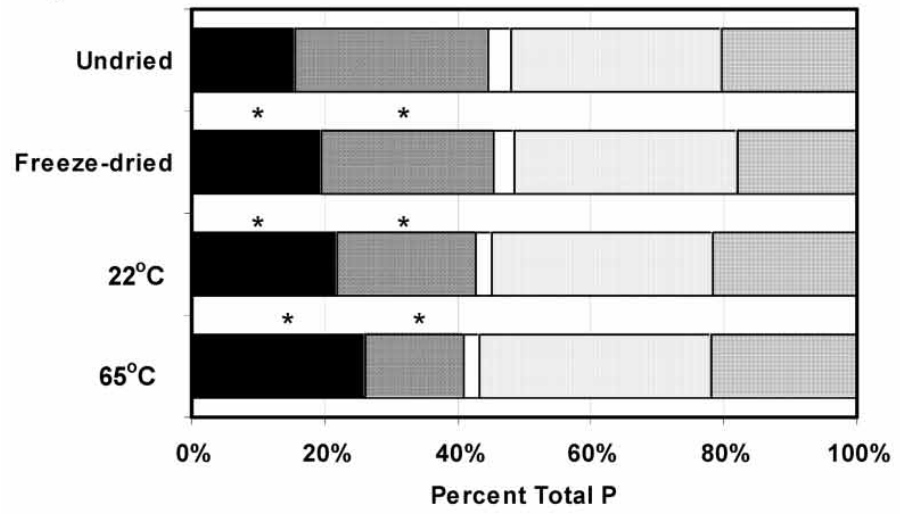

- Water-P $\square$ Bicarbonate-P $\square$ Hydroxide-P $\square$ Acid-P $\square$ Residual-P

Figure 1. Effects of drying on total P distribution in sequentially extracted fractions of poultry manure. Symbol * indicates significant difference $(\alpha=0.05)$ from undried manure. 
dried samples were seen in PM-2. No significant drying effect was observed on $\mathrm{NaOH}$-extractable $\mathrm{P}$ in PM-3. Different types of organic amendments may also differ in response of $\mathrm{NaOH}$-extractable $\mathrm{P}$ to drying. As an example, $105^{\circ} \mathrm{C}$ drying decreased $\mathrm{NaOH}$-extractable $\mathrm{P}$ in beef manures and biosolids but increased it in swine manure (Ajiboye, Akinremi, and Racz 2004).

Both $65^{\circ} \mathrm{C}$ and $22^{\circ} \mathrm{C}$ drying increased $\mathrm{HCl}$-extractable $\mathrm{P}$ in PM-1 by $33 \%$ but had no effect on PM-2 or PM-3. Residual P, the portion of P left in the manure after all extractions, was disparately affected by drying. One manure, PM-1, had about $75 \%$ less residual $\mathrm{P}$ after both $65^{\circ} \mathrm{C}$ and $22^{\circ} \mathrm{C}$ drying but was relatively unchanged by freeze drying. Drying had no effect on the calculated concentration of residual P in either PM-2 or PM-3. The variation associated with drying effects on less labile and residual $\mathrm{P}$ forms is consistent with work by Ajiboye, Akinremi, and Racz (2004), in which $105^{\circ} \mathrm{C}$ drying increased $\mathrm{HCl}$-extractable $\mathrm{P}$ and decreased residual $\mathrm{P}$ in dairy and beef manures but had no effect on swine manure.

Transformation of $\mathrm{P}$ from one fraction to another as a result of sample drying has been previously reported (Ajiboye, Akinremi, and Racz 2004; Sistani et al. 2001). Heat associated with oven drying may change the solubility of some $\mathrm{P}$ forms, leading to elevated levels of $\mathrm{H}_{2} \mathrm{O}$-soluble phosphorus. Ajiboye, Akinremi, and Racz (2004) noted that oven-dried manures from dairy and swine manures have lower $\mathrm{NaHCO}_{3}$-extractable $\mathrm{P}$ content than undried samples, suggesting transformation of $\mathrm{P}$ forms in these organic amendments. The boiling process involved with high-temperature oven drying could cause the hydrolysis of $\mathrm{NaHCO}_{3}$-extractable $\mathrm{P}_{\mathrm{o}}$ as well as the desorption of $\mathrm{P}$ that is held on the surfaces of organic and inorganic colloids in dairy manure. Desorbed $\mathrm{P}$ could then appear in the $\mathrm{H}_{2} \mathrm{O}$-extractable fraction of the oven-dried samples. Other researchers have noted a shift toward more stable and recalcitrant $\mathrm{P}$ forms after manure drying. McDowell and Stewart (2005) examined fresh and air-dried dung samples from grazing ruminants (dairy cattle, deer, and sheep) using sequential fractionation and solid-state ${ }^{31} \mathrm{P}$ nuclear magnetic resonance (NMR) spectra, revealing that the labile $\mathrm{P}$ in fresh manures shifted into the more recalcitrant $\mathrm{HCl}$ and residual fractions with air drying.

\section{Effects of Drying on Organic and Inorganic Phosphorus Fractions}

To further evaluate the effects of drying on $\mathrm{P}$ distribution, sequentially extracted $\mathrm{P}$ was separated into $\mathrm{P}_{\mathrm{i}}$ and $\mathrm{P}_{\mathrm{o}}$ (Table 3). Water extracts of undried manures contained primarily $\mathrm{P}_{\mathrm{i}}$, comprising $73-94 \% \quad \mathrm{H}_{2} \mathrm{O}-$ and $64-87 \% \mathrm{NaHCO}_{3}-\mathrm{P}_{\text {tot }}$. In contrast, Sistani et al. (2001) reported that $72-$ $83 \%$ of $\mathrm{H}_{2} \mathrm{O}$-extractable poultry manure $\mathrm{P}$ was in organic forms.

In PM-3, $\mathrm{P}_{\mathrm{i}}$ content determined by a modified molybdenum blue method was greater than total $\mathrm{P}$ determined by ICP-AES for both the $\mathrm{H}_{2} \mathrm{O}$ and 
Table 3. Effects of drying on inorganic $\left(\mathrm{P}_{\mathrm{i}}\right)$ and organic phosphorus $\left(\mathrm{P}_{\mathrm{o}}\right)$ distribution in sequentially extracted fractions of poultry manure $\left(\mathrm{g} \mathrm{P} \mathrm{kg}^{-1}\right.$ dry matter $)^{a}$

\begin{tabular}{|c|c|c|c|c|c|c|c|c|}
\hline Treatment & \multicolumn{2}{|c|}{$\mathrm{H}_{2} \mathrm{O}$} & \multicolumn{2}{|c|}{$\mathrm{NaHCO}_{3}$} & \multicolumn{2}{|c|}{$\mathrm{NaOH}$} & \multicolumn{2}{|c|}{$\mathrm{HCl}$} \\
\hline Undried & $1.08 \mathrm{c}^{b}$ & $0.39 \mathrm{c}$ & $1.71 \mathrm{a}$ & $0.95 \mathrm{a}$ & $0.31 \mathrm{a}$ & $0.85 a$ & $3.26 \mathrm{~b}$ & $1.93 b$ \\
\hline Freeze dry & $1.27 \mathrm{~b}$ & $0.58 \mathrm{bc}$ & $1.09 \mathrm{c}$ & $0.63 \mathrm{a}$ & $0.24 \mathrm{a}$ & $0.46 \mathrm{~b}$ & $2.67 \mathrm{c}$ & $3.29 \mathrm{a}$ \\
\hline $22^{\circ} \mathrm{C}$ & $1.50 \mathrm{a}$ & $0.83 \mathrm{a}$ & $1.52 \mathrm{ab}$ & $0.66 \mathrm{a}$ & $0.27 \mathrm{a}$ & $0.60 \mathrm{~b}$ & $3.60 \mathrm{a}$ & $4.26 \mathrm{a}$ \\
\hline \multicolumn{9}{|l|}{ PM-2 } \\
\hline Undried & $3.05 \mathrm{~b}$ & $0.76 a$ & $6.06 \mathrm{a}$ & $0.89 \mathrm{a}$ & $0.44 \mathrm{a}$ & $0.82 \mathrm{a}$ & $6.57 \mathrm{a}$ & $1.92 \mathrm{a}$ \\
\hline Freeze dry & $4.17 \mathrm{ab}$ & $1.00 \mathrm{a}$ & $3.11 \mathrm{c}$ & $0.56 \mathrm{a}$ & $0.34 \mathrm{c}$ & $0.38 \mathrm{c}$ & $6.25 \mathrm{a}$ & $2.23 \mathrm{a}$ \\
\hline $22^{\circ} \mathrm{C}$ & $4.12 \mathrm{ab}$ & $0.90 \mathrm{a}$ & $4.55 b$ & $0.51 \mathrm{a}$ & $0.40 \mathrm{ab}$ & $0.66 \mathrm{ab}$ & $7.06 \mathrm{a}$ & $2.57 \mathrm{a}$ \\
\hline $65^{\circ} \mathrm{C}$ & $5.10 \mathrm{a}$ & $1.10 \mathrm{a}$ & $3.41 \mathrm{c}$ & $0.73 a$ & $0.36 \mathrm{bc}$ & $0.47 b c$ & $6.69 a$ & $2.52 \mathrm{a}$ \\
\hline \multicolumn{9}{|l|}{ PM-3 } \\
\hline Undried & $4.08 \mathrm{~d}$ & 0.26 & $8.60 \mathrm{a}$ & - & $0.71 \mathrm{a}$ & $0.23 \mathrm{a}$ & $6.68 \mathrm{a}$ & $2.48 \mathrm{a}$ \\
\hline
\end{tabular}

${ }^{a}$ Dry matter based on $65^{\circ} \mathrm{C}$-dry sample.

${ }^{b}$ Averages followed by the same letter within columns for each manure are not significantly different $(\alpha=0.05)$.

${ }^{c}$ Calculated results had negative values. 
$\mathrm{NaHCO}_{3}$ fractions. However, hydrolysis by phosphatase enzymes did indicate that PM-3 contained about $0.1 \mathrm{~g} \mathrm{P} \mathrm{kg}^{-1}$ as $\mathrm{P}_{\mathrm{o}}$ (data not shown). Disagreement between ICP and colorimetric methods of phosphorus quantification has been noted previously (Wolf 2005). The commonly used Murphy and Riley colorimetric procedure measures primarily orthophosphate $\mathrm{P}$, although some organic P compounds can by hydrolyzed by acidic reagents in the assay (Dick and Tabatabai 1977; Murphy and Riley 1962). A modification proposed by Dick and Tabatabai (1977) was utilized, involving the addition of a citrate-arsenite reagent to complex with excess molybdate ions and prevent further formation of blue color from acid-hydrolyzed $\mathrm{P}$ in the assay. Wolf et al. (2005) proposed that higher P measurements of manure extracts determined with the Murphy and Riley colorimetric procedure were the result of color interference, as extracts can be brown or amber after centrifugation and filtration. Results from ICP and the Murphy and Riley procedure are generally correlated within 5 to $10 \%$ of each other (Wolf et al. 2005). In the current study, $\mathrm{NaHCO}_{3}$ and $\mathrm{NaOH}$ extracts of our poultry manures did exhibit brown coloration. The proportion of total $\mathrm{P}$ in organic forms was greater in the $\mathrm{NaOH}$ and $\mathrm{HCl}$ fractions than the more labile fractions of our manures. Undried PM-1 and PM-2 had $\mathrm{P}_{\mathrm{o}}$ concentrations representing 65\% and $73 \%$ of $\mathrm{NaOH}$-extractable $\mathrm{P}$, respectively. In $\mathrm{HCl}$ fractions, $23-37 \%$ of extractable $\mathrm{P}$ was $\mathrm{P}_{\mathrm{o}}$. This observation supported the previous argument that it should not be simply assumed that sequentially extracted $1 \mathrm{M} \mathrm{HCl}$ fractions contained no organic $\mathrm{P}$ ( $\mathrm{He}$ et al. 2006b).

Drying produced changes in manure $\mathrm{H}_{2} \mathrm{O}$-extractable $\mathrm{P}_{\mathrm{i}}$ content. Drying at $65^{\circ} \mathrm{C}$ increased $\mathrm{H}_{2} \mathrm{O}$-extractable $\mathrm{P}_{\mathrm{i}}$ in all three manures by $47-92 \%$ (Table 3). Freeze- and $22^{\circ} \mathrm{C}$-dried samples of PM-1 and PM-3 also had higher $\mathrm{H}_{2} \mathrm{O}$-extractable $\mathrm{P}_{\mathrm{i}}$ than undried manures. Drying and grinding have been reported to change $P_{i}$ solubility in dairy manure, resulting in lower $\mathrm{H}_{2} \mathrm{O}$-extractable $\mathrm{P}_{\mathrm{i}}$ in $65^{\circ} \mathrm{C}$-dried material (Chapuis-Lardy et al. 2004). Very little change was observed in $\mathrm{H}_{2} \mathrm{O}$-soluble $\mathrm{P}_{\mathrm{o}}$ with drying. In one manure, PM-1, there was a slight increase in $\mathrm{P}_{\mathrm{o}}$ with $22^{\circ} \mathrm{C}$ and $65^{\circ} \mathrm{C}$ drying. This is consistent with other reports of $\mathrm{H}_{2} \mathrm{O}$-extractable $\mathrm{P}_{\mathrm{o}}$ being relatively unaffected by drying (Akinremi et al. 2003).

Drying also had an effect on $\mathrm{NaHCO}_{3}$-extractable $\mathrm{P}_{\mathrm{i}}$, with as much as an $80 \%$ decrease in $65^{\circ} \mathrm{C}$-dried manure. Magnitude of the drying effect was different between manures, but $65^{\circ} \mathrm{C}$ and freeze drying had significant effects on $\mathrm{NaHCO}_{3}$-extractable $\mathrm{P}_{\mathrm{i}}$ from all three manures. There was no effect of drying on $\mathrm{NaHCO}_{3}$-extractable $\mathrm{P}_{\mathrm{o}}$. NaOH-extractable $\mathrm{P}_{\mathrm{i}}$ was largely unaffected by drying, with the exception of a reduction from 0.44 to about $0.35 \mathrm{~g} \mathrm{P}_{\mathrm{i} \mathrm{kg}}^{-1}$ in PM-2 due to $65^{\circ} \mathrm{C}$ drying. Organic $\mathrm{P}$ extracted by $\mathrm{NaOH}$ was reduced by all drying types in PM-1 (up to $85 \%$ ) and by freeze and $65^{\circ} \mathrm{C}$ drying in PM-2. McDowell and Stewart (2005) found that $\mathrm{NaOH}-$ extractable $\mathrm{P}_{\mathrm{o}}$ was the only fraction of $\mathrm{P}_{\mathrm{o}}$ to significantly change in airdried compared to undried animal dung. In this study, $\mathrm{HCl}$-extractable $\mathrm{P}_{\mathrm{i}}$ in PM-1 was reduced by freeze drying but slightly increased by $22^{\circ} \mathrm{C}$ and 
$65^{\circ} \mathrm{C}$ drying. In addition, all drying methods resulted in higher $\mathrm{HCl}-$ extractable $\mathrm{P}_{\mathrm{o}}$ concentrations in PM-1 compared to undried manures. No effect was observed of drying on HCl-extractable P in either PM-2 or PM-3.

Analysis using ${ }^{31} \mathrm{P}$ NMR on animal dung by McDowell and Stewart (2005) showed that air drying changes $\mathrm{P}_{\mathrm{o}}$ concentration, possibly due to degradation of diesters. Gerritse and Eksteen (1978), in a study using high performance liquid chromatography (HPLC) analysis of gel filtrations of swine manure, observed that desiccation by oven $\left(60\right.$ and $\left.100^{\circ} \mathrm{C}\right)$ and freeze drying did not result in an overall change in the quantity of manure $\mathrm{P}_{\mathrm{o}}$ present. However, these researchers did find that high-molecular-weight $P_{o}$ decreased after oven drying and subsequent rewetting. Increases in $\mathrm{P}_{\mathrm{i}}$ solubility as well as transformation of $\mathrm{P}_{\mathrm{o}}$ from the $\mathrm{NaOH}$ to the $\mathrm{HCl}$ fraction in our poultry manures further the view that manure $\mathrm{P}$ cannot be assumed to behave equivalently after drying. Summation of $\mathrm{P}_{\mathrm{i}}$ and $\mathrm{P}_{\mathrm{o}}$ values from the sequential fractions in Table 3 revealed that total $\mathrm{P}$ concentration of PM-1 and PM-2 did not change significantly with drying (data not shown). It is assumed that incorporation of $\mathrm{P}_{\mathrm{o}}$ into stable aggregates during the drying process is the cause of increased $P_{o}$ stability rather than heat-associated degradation of $\mathrm{P}_{\mathrm{o}}$ into orthophosphate.

\section{Effect of Drying on Metal Cation Concentrations and Relationship to $\mathbf{P}$ Distribution}

The manures contained 7 (PM-1) and 11 (PM-2 and PM-3) $\mathrm{g} \mathrm{kg}^{-1}$ of magnesium $(\mathrm{Mg})$ (Table 1). Calcium (Ca) content of the manures was 153 (PM-1), 152 (PM-2), and 70 (PM-3) $\mathrm{g} \mathrm{kg}^{-1}$. These differences are probably related to across-farm differences in animal rations as well as dietary differences due to bird production status. To explore the chemistry behind drying effects on labile $\mathrm{P}$ change, the relationship of $\mathrm{P}$ to $\mathrm{Ca}$ and $\mathrm{Mg}$ content in $\mathrm{H}_{2} \mathrm{O}$ and $\mathrm{NaHCO}_{3}$ fractions of poultry manure were examined. Significant differences were found in the ratio of $\mathrm{P}_{\mathrm{i}}$ to $\mathrm{Ca}$ in $\mathrm{H}_{2} \mathrm{O}$-extractable $\mathrm{P}$ with $22^{\circ} \mathrm{C}$ drying (all three manures), freeze drying (PM-1), and $65^{\circ} \mathrm{C}$ drying (PM-1 and PM-3) (Table 4). In addition, $\mathrm{P}_{\text {tot }}$ to $\mathrm{Ca}$ ratios in these manures roughly paralleled the results of $\mathrm{P}_{\mathrm{i}}$ to Ca ratios, indicating that the differences were due to $P_{i}$ rather than the $P_{o}$ component of $P_{\text {tot }}$. In PM-2, the $P_{i}$ and $P_{\text {tot }}$ to Ca ratios increased with all drying methods. However, freeze and oven drying decreased the ratios of $\mathrm{P}_{\mathrm{i}}$ and $\mathrm{P}_{\text {tot }}$ to $\mathrm{Ca}+\mathrm{Mg}$, thus suggesting that $\mathrm{Mg}$ may play a larger role in this particular manure. Similar analysis of $\mathrm{NaHCO}_{3^{-}}$ extractable $\mathrm{P}_{\mathrm{i}}$ and $\mathrm{P}_{\text {tot }}$ revealed that $\mathrm{P}_{\mathrm{i}}$ and $\mathrm{P}_{\text {tot }}$ to Ca ratios change significantly with freeze and oven drying in all three manures. Kleinman et al. (2005) found positive correlations between water-extractable $\mathrm{P}$ and $\mathrm{Ca}, \mathrm{Mg}$, and $\mathrm{Fe}$ from livestock manure. Furthermore, drying can reduce water-extractable $\mathrm{Ca}$ and $\mathrm{Mg}$ in broiler manure, with the greatest reduction seen in air- and $65^{\circ} \mathrm{C}$ dried samples (Sistani et al. 2001). Phosphorus solubility in poultry manure has been proposed to be controlled by solid mineral P phases (Sistani et al. 
Table 4. Molar ratio of inorganic $\left(\mathrm{P}_{\mathrm{i}}\right)$ or total $\left(\mathrm{P}_{\text {tot }}\right) \mathrm{P}$ to $\mathrm{Ca}$ and $\mathrm{Mg}$ in $\mathrm{H}_{2} \mathrm{O}$ and $\mathrm{NaHCO}_{3}$ fractions of poultry manure

${ }^{a}$ Averages followed by the same letters within columns for each manure are not significantly different $(\alpha=0.05)$. 


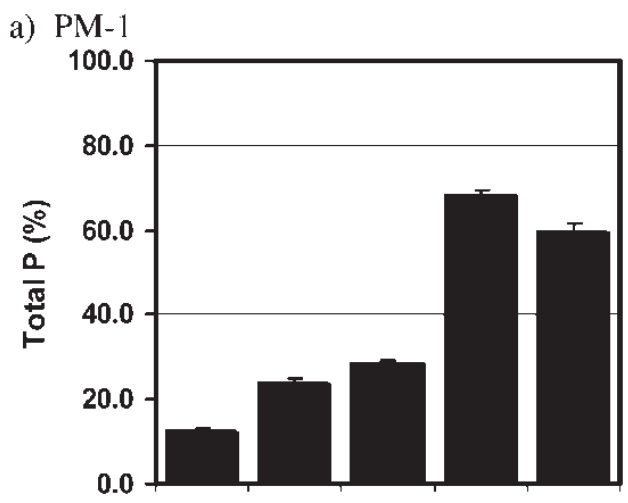

b) PM-2

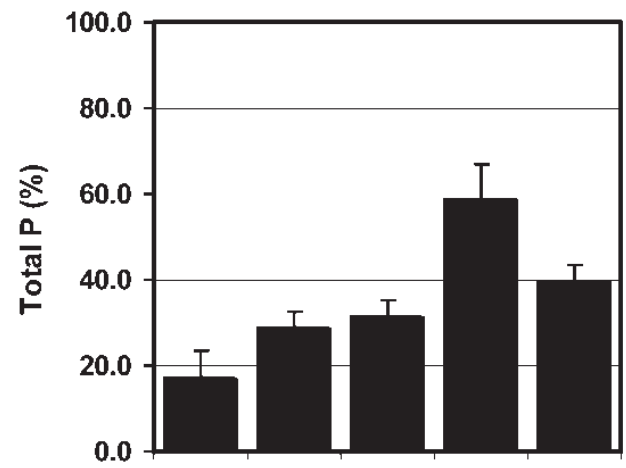

b) $\mathrm{PM}-3$

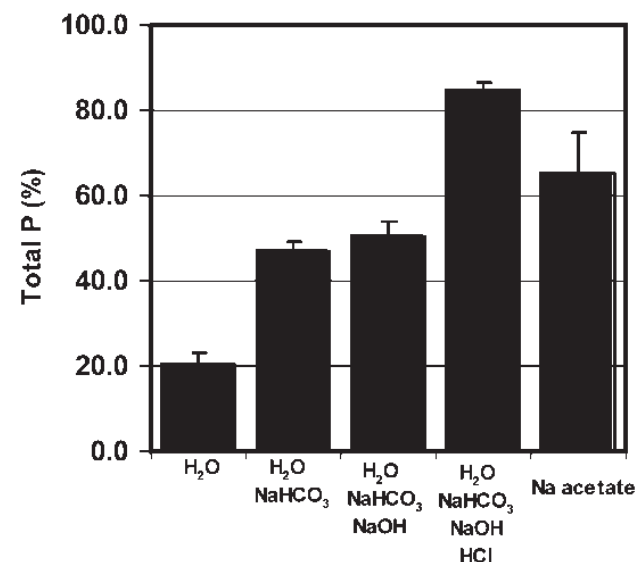

Figure 2. Comparison of $\mathrm{P}$ extracted by sodium acetate buffer (100 mM, pH 5.0) with that from sequential fractions of freeze-dried poultry manure. Horizontal bars represent standard deviations $(n=9)$. 
2001). Studies by Ajiboye, Akinremi, and Racz (2004), Sharpley and Moyer (2000), and Dou et al. (2000) showed that the concentrations of $\mathrm{Ca}, \mathrm{Al}$, and $\mathrm{Fe}$ control P solubility in manure. Positive correlations between water-extractable $\mathrm{Ca}$ and $\mathrm{P}$ and the presence of $\mathrm{Ca}$ as the dominant manure cation suggest that Ca-P forms would control P solubility (Dou et al. 2000; Kleinman et al. 2005). This work supports this proposition.

\section{Comparison of Acetate Buffer-Extracted P to That from Sequential Extractions}

Sodium acetate buffer (100 mM, pH 5.0) has been tested as a single extractant to determine plant-available $\mathrm{P}$ in dairy manures because extraction conditions are close to those for Morgan (1.24 M sodium acetate buffer, $\mathrm{pH} 4.8$ ) or modified Morgan $\mathrm{P}\left[0.62 \mathrm{M}\right.$ ammonium oxide $\left(\mathrm{NH}_{4} \mathrm{OH}\right)+1.25 \mathrm{M}$ acetic acid, $\mathrm{pH} 4.8$ ], which have been used for soil $\mathrm{P}$ testing (Akinremi et al. 2003; Griffin, Honeycutt, and He 2003; He, Griffin, and Honeycutt 2004b). $\mathrm{He}$, Griffin, and Honeycutt (2004b) found that dairy manure P extracted by acetate buffer was equivalent to the summed amount of $\mathrm{P}$ removed by $\mathrm{H}_{2} \mathrm{O}$, $\mathrm{NaHCO}_{3}$, and $\mathrm{NaOH}$ sequential fractions. In this study, poultry manure contained small quantities of $\mathrm{NaOH}$-extractable $\mathrm{P}$ and a relatively large amount of $\mathrm{HCl}$-extractable $\mathrm{P}$ (Figure 1), thus providing an opportunity to verify the correlation between acetate buffer-extracted $\mathrm{P}$ and sequentially extracted P. In PM-1, acetate extractable $\mathrm{P}$ was two times higher than that extracted by $\mathrm{H}_{2} \mathrm{O}, \mathrm{NaHCO}_{3}$, and $\mathrm{NaOH}$ together but less than the total extracted by $\mathrm{H}_{2} \mathrm{O}, \mathrm{NaHCO}_{3}, \mathrm{NaOH}$, and $\mathrm{HCl}$ (Figure 2). Similarly, acetateextractable $\mathrm{P}$ was about $22 \%$ higher in PM-2 and PM-3 than $\mathrm{H}_{2} \mathrm{O}$, $\mathrm{NaHCO}_{3}$, and $\mathrm{NaOH}$ but less than the total extracted by $\mathrm{H}_{2} \mathrm{O}, \mathrm{NaHCO}_{3}$, $\mathrm{NaOH}$, and $\mathrm{HCl}$, suggesting that the $\mathrm{NaOH}-\mathrm{P}$ fraction of animal manure is extractable by sodium acetate buffer. These observations imply that whereas sequentially extracted $\mathrm{NaOH}-$ and $\mathrm{HCl}$-extractable $\mathrm{P}$ in soil are considered less plant available than $\mathrm{H}_{2} \mathrm{O}$ and $\mathrm{NaHCO}_{3}$ fractions (Cross and Schlesinger 1995), the counterpart $P$ in animal manure should not be assumed to be so.

\section{CONCLUSIONS}

Using the sequential fractionation procedure, the effects of drying process on the $\mathrm{P}$ distribution in poultry manures was investigated. In the three manures tested, the most significant change was observed in the water-soluble $\mathrm{P}$ fraction. The concomitant increase in $\mathrm{H}_{2} \mathrm{O}$-extractable $\mathrm{P}$ and decrease in $\mathrm{NaHCO}_{3}$-extractable $\mathrm{P}$ with drying suggests that a transformation occurred whereby $\mathrm{P}$ was becoming more labile under the influence of heat associated with drying. In addition, changes were observed in $\mathrm{NaOH}$-extractable $\mathrm{P}$ and $\mathrm{HCl}$-extractable $\mathrm{P}$ from one manure, leading to decreases in the amount of 
recalcitrant and residual $\mathrm{P}$ after drying. It seems that the drying process caused moderately stable $\mathrm{P}$ in poultry manure to either become more labile or more recalcitrant. This bilateral trend might partly explain the inconsistent observations of drying reported by other research groups. Therefore, the variations due to drying effects should be taken into consideration when evaluating manures for $\mathrm{P}$ availability or when comparing data in which different drying methods have been utilized.

\section{REFERENCES}

Ajiboye, B., Akinremi, O.O., and Racz, G.J. (2004) Laboratory characterization of phosphorus in fresh and oven-dried organic amendments. Journal of Environmental Quality, 33: 1062-1069.

Akinremi, O.O., Armisen, N., Kashem, M.A., and Janzen, H.H. (2003) Evaluation of analytical methods for total phosphorus in organic amendments. Communications in Soil Science and Plant Analysis, 34: 2981-2991.

Chapuis-Lardy, L., Fiorini, J., Toth, J.D., and Dou, Z. (2004) Phosphorus concentration and solubility in dairy feces: Variability and affecting factors. Journal of Dairy Science, 87: 4334-4341.

Cross, A.F. and Schlesinger, W.H. (1995) A literature review and evaluation of the Hedley fractionation: Applications to the biogeochemical cycle of soil phosphorus in natural ecosystems. Geoderma, 64: 197-214.

Dick, W.A. and Tabatabai, M.A. (1977) Determination of orthophosphate in aqueous solutions containing labile organic and inorganic phosphorus compounds. Journal of Environmental Quality, 6: 82-85.

Dou, Z., Toth, J.D., Galligan, D.T., Ramberg, C.F., Jr., and Ferguson, J.D. (2000) Laboratory procedures for characterizing manure phosphorus. Journal of Environmental Quality, 29: 508-514.

Elias-Azar, K., Laag, A.E., and Pratt, P.F. (1980) Bicarbonate-extractable phosphorus in fresh and composted dairy manures. Soil Science Society of America Journal, 44: $435-443$.

Gerritse, R.G. and Eksteen, R. (1978) Dissolved organic and inorganic phosphorus compounds in pig slurry: Effect of drying. Journal of Agricultural Science, Cambridge, 90: 39-45.

Griffin, T.S., Honeycutt, C.W., and He, Z. (2003) Changes in soil phosphorus from manure application. Soil Science Society of America Journal, 67: 645-643.

He, Z., Fortuna, A., Senwo, Z.N., Tazisong, I.A., Honeycutt, C.W., and Griffin, T.S. (2006b) Hydrochloric fractions in Hedley fractionation may contain inorganic and organic phosphates. Soil Science Society of America Journal, 70: 893-899.

He, Z. and Honeycutt, C.W. (2005) A modified molybdate blue method for orthophosphate determination suitable for investigating enzymatic hydrolysis of organic phosphates. Communications in Soil Science and Plant Analysis, 36: 1373-1383.

He, Z., Griffin, T.S., and Honeycutt, C.W. (2004a) Enzymatic hydrolysis of organic phosphorus in swine manure and soils. Journal of Environmental Quality, 33: 367-372.

He, Z., Griffin, T.S., and Honeycutt, C.W. (2004b) Phosphorus distribution in dairy manures. Journal of Environmental Quality, 33: 1528-1534. 
He, Z., Senwo, Z.N., Mankolo, R.N., and Honeycutt, C.W. (2006a) Phosphorus fractions in poultry litter characterized by sequential fractionation coupled with phosphatase hydrolysis. Journal of Food, Agriculture and Environment, 4: 304-312.

Hedley, M.J., Stewart, J.W.B., and Chauhan, B.S. (1982) Changes in inorganic and organic soil phosphorus fractions induced by cultivation practices and by laboratory incubations. Soil Science Society of America Journal, 46: 970-976.

Kleinman, P.J.A., Sharpley, A.N., Wolf, A.M., Beegle, D.B., and Moore, P.A. Jr., (2002) Measuring water-extractable phosphorus in manure as an indicator of phosphorus in runoff. Soil Science Society of America Journal, 66: 2009-2015.

Kleinman, P.J.A., Wolf, A.M., Sharpley, A.N., Beegle, D.B., and Saporito, L.S. (2005) Survey of water-extractable phosphorus in livestock manures. Soil Science Society of America Journal, 69: 701-708.

Leinweber, P., Haumaier, L., and Zech, W. (1997) Sequential extractions and ${ }^{31} \mathrm{P}$ NMR spectroscopy of phosphorus forms in animal manures, whole soils and particle-size separates from a densely populated livestock area in northwest Germany. Biology and Fertility of Soils, 25: 89-94.

McDowell, R.W. and Stewart, I. (2005) Phosphorus in fresh and dry dung of grazing dairy cattle, deer, and sheep: Sequential fraction and phosphorus-31 nuclear magnetic resonance analyses. Journal of Environmental Quality, 34: 598-607.

Murphy, J. and Riley, J.P. (1962) A modified single solution method for the determination of phosphate in natural waters. Analytica Chimica Acta, 27: 31-36.

SAS Institute. (1999) SAS Procedures Guide, Version 7. SAS Institute: Cary, N.C.

Schlichting, A. and Leinweber, P. (2002) Effects of pretreatment on sequentially extracted phosphorus fractions from peat soils. Communications in Soil Science and Plant Analysis, 33: 1617-1627.

Scholl, D.W., Bolton, A.J., Clennell, M.B., and Spence, G.D. (1997) Comparison of Shipboard Porosity Values using Oven- and Freeze-Drying Techniques: Site 1039, 1040, and 1043. College State, Tex.: Ocean Drilling Program. 540-550.

Sharpley, A.N. and Moyer, B. (2000) Phosphorus forms in manure and compost and their release during simulated rainfall. Journal of Environmental Quality, 29: $1462-1469$

Sistani, K.R., Miles, D.M., Rowe, D.E., Brink, G.E., and McGowen, S.L. (2001) Impact of drying method, dietary phosphorus levels, and methodology on phosphorus chemistry of broiler manure. Communications in Soil Science and Plant Analysis, 32: 2783-2793.

Twinch, A.J. (1987) Phosphate exchange characteristics of wet and dried sediment samples from a hypertrophic reservoir: Implications for the measurements of sediment phosphorus status. Water Resources, 21: 1225-1230.

Wolf, A.M., Kleinman, P.J.A., Sharpley, A.N., and Beegle, D.B. (2005) Development of a water-extractable phosphorus test for manure: An interlaboratory study. Soil Science Society of America Journal, 69: 695-700. 